\title{
Kajian Potensi Air Tanah Berdasarkan Data Geolistrik Resistiviti Untuk Antisipasi Kekeringan Di Wilayah Pesisir Kangkung, Kabupaten Kendal, Privinsi Jawa Tengah
}

\author{
Sugeng Widada*, Alfi Satriadi dan Baskoro Rochaddi \\ Departemen Oseanografi, Fakultas Perikanan dan Ilmu Kelautan, Universitas Diponegoro, \\ JI. Prof. Soedarto, SH. Kampus UNDIP Tembalang, Semarang 50275 \\ Email : sugengwidada@undip.ac.id
}

\begin{abstract}
Coastal Region of Kangkung, Kendal Regency, Central Java Province is one of the areas that experiencing water in the dry season. Groundwater exploitation is one way solution to meet the water needs for people in the area, especially in the dry season. Therefore it is necessary to study potency of ground water in coastal area of Kangkung. The research was conducted to determine the potential of ground water in the confined aquifer in the Coastal Region of Kangkung, Kendal District which is expected to be utilized as a source of water to meet the needs of local communities. The method used in this research is descriptive analysis to describe the condition of aquifer, however some things are delivered quantitatively. The aquifer condition was obtained from the interpretation of geoelectricity (resistivity) data supported by geological and hydrogeological observation data and pumping test data as secondary data. Groundwater quality analysis and simple hydrochemical analysis is with Chlorida - Bicarbonat Ratio (CBR) method to know the possibility of sea water intrusion. The results showed that the aquifer in the coastal area of Kangkung has the potential of 29.13 It / sec ground water discharge which can be utilized to meet the needs of clean water 18,800 people. Although it is adjacent to the sea, the groundwater in the study area does not undergo sea water intrusion. Groundwater quality in this location is qualified as raw drinking water according to SK Menkes No, 492/Menkes/Per/IV2010 tentang Persyaratan Kualitas Air Minum.
\end{abstract}

Keywords: ground water, geoelectric, intrusion

\section{Abstrak}

Wilayah Pesisir Kangkung, Kabupaten Kendal Provinsi Jawa Tengah merupakan salah satu daerah yang pada musim kemarau mengalami kekeringan. Pemanfaatan air tanah merupakan salah satu cara untuk memenuhi kebutuhan air bagi masyarakat di daerah tersebut, terutama pada musim kemarau. Oleh karena itu perlu dilakukan kajian potensi air tanah di daerah Pesisir Kangkung tersebut. Penelitian ini bertujuan untuk mengetahui potensi air tanah pada akuifer dalam (tertekan) di Wilayah Pesisir Kangkung, Kabupaten Kendal yang diharapkan dapat dimanfaatkan sebagai sumber air bersih untuk memenuhi kebutuhan masyarakat setempat. Metode penelitian yang digunakan dalam penelitian ini adalah diskriptis analisis untuk menggambarkan kondisi akuifer, namun demikian beberapa hal disampaikan secara kuantitatif. Kondisi akuifer diperoleh dari hasil interpretasi data geolistrik resistiviti dengan didukung data hasil pengamatan geologi dan hidrogeologi serta data sekunder berupa hasil pumping test. Analisa kualitas air tanah dan analisis hidrokimia secara sederhana dengan metode Chlorida - Bicarbonat Ratio (CBR) dilakukan untuk mengetahui kemungkinan terjadinya intrui air laut. Hasil penelitian menujukan bahwa akuifer di daerah Pesisir Kangkung mempunyai potensi debit air tanah 29,13 It/det yang dapat dimanfaatkan untuk memenuhi kebutuhan air bersih 18.800 orang. Meskipun berbatasan dengan laut, namun air tanah di daerah kajian tidak mengalami terintrusi air laut. Kualitas air tanah di lokasi ini memenuhi syarat sebagai bahan baku air minum sesuai SK Menkes No, 492/Menkes/Per/IV2010 tentang Persyaratan Kualitas Air Minum.

Kata Kunci : air tanah, geolistrik, intrusi 


\section{PENDAHULUAN}

Air merupakan salah satu sumberdaya alam yang merupakan kebutuhan hidup yang sangat penting dan merupakan unsur dasar bagi semua peri kehidupan di bumi. Tanpa air, berbagai proses kehidupan baik untuk hewan, tumbuhan dan manusia tidak akan dapat berlangsung. Pada saat ini, air telah dimanfaatkan tidak saja untuk keperluan konsumsi, pertanian dan transportasi tetapi telah meluas ke sektor rekreasi dan industri. Meskipun air merupakan komposisi terbesar di bumi (berkisar $70 \%$ ), namun yang dapat dipergunakan oleh manusia hanyalah 0,7 $\%$, baik berupa airtanah dan air permukaan. Sedangkan sisanya $97,2 \%$ lautan dan 2,1 \% berupa es di kutub (Hendrayana, 2004).

Pemanfaatan sumber daya air untuk berbagai keperluan di satu pihak terus meningkat dari tahun ke tahun, sebagai dampak pertumbuhan penduduk dan pengembangan aktivitasnya. Di lain pihak ketersediaan sumber daya air semakin terbatas bahkan cenderung semakin langka, terutama akibat penurunan kualitas lingkungan dan penurunan kualitas air akibat pencemaran. Berkaitan dengan hal tersebut, maka pemanfaatan air tanah untuk memenuhi kebutuhan air bersih tidak dapat dielakan dan merupakan alternative pilihan utama yang banyak dipilih walaupun seharusnya pemanfaatan air tanah adalah merupakan pilihan terakhir demi kelangsungan keberadaan sumber air itu sendiri.

Keberadaan air tanah tidaklah merata untuk setiap tempat dan sangat terkait dengan kondisi geologi dan geohidrologinya. Oleh kerena itu penyediaan air bersih dengan pemanfaatan air tanah harus dilakukan melalui kajian potensi air tanah di daerah yang bersangkutan. Wilayah Pesisir Kangkung, Kabupaten Kendal Provinsi Jawa Tengah merupakan salah satu daerah yang pada musim kemarau mengalami kekeringan. Oleh karena itu perlu adanya tindakan antisipasi untuk tetap memenuhi kebutuhan air bersih secara permanen. Berkaitan dengan hal tersebut, maka perlu adanya upaya eksplorasi air tanah guna memperoleh informasi data tentang potensi air tanah yang kemungkinan bisa dikembangkan dengan tetap memperhatikan kelestarian lingkungan. Untuk mengetahui kondisi akuifer yang tergandung kondisi geologi bawah permukaan wilayah tersebut dapat dilakukan salah satunya adalah dengan metode geolistrik resistiviti.

Penelitian terdahulu terkait penggunaan metode geolistrik untuk mengetahui kondisi geologi bawah permukaan telah banyak dilakukan diantaranya oleh Putriutami, et al. (2012) yang melakukan survey geolitrik untuk mengetahui geologi bawah permukaan di area panas bumi Telomoyo, Guenerger, et al. (2014) yang menggunakan metode geolistrik untuk mengetahui struktur bawah permukaan di area panas bumi Kendalisodo, dan Ahmad, et al. (2016) yang melakukan identifikasi batupasir sebagai akuifer dengan aplikasi geolistrik konfigurasi schlumberger. Mengacu berbagai hasil penelitian terdahulu terlihat bahwa kondisi geologi bawah permukaan yang unik dapat diprakirakan dengan metode geolistrik. Berdasarkan hal tersebut, maka dilakukan kajian potensi air tanah di wilayah Peisisr Kangkung Kabupaten Kendal untuk mengatisipasi kekeringan yang senantiasa melanda daerah tersebut setiap musim kemarau.

\section{MATERI DAN METODE}

Materi yang digunakan dalam penelitian ini meliputi data primer dan data sekunder. Data primer berupa data hasil pengukuran geolistrik resistiviti dengan konfigurasi schlumberger. Sedangkan data sekunder berupa peta geologi, peta hidrogeologi dan data pumping test. Secara umum metode yang digunakan dalam penelitian ini adalah metode diskriptis analisis untuk menggambarkan kondisi akuifer namun demikian beberapa hal disampaikan secara kuantitatif.

Penelitian ini dilakukan di Wilayah Pesisir Kecamatan Kangkung Kabupaten 
Kendal Provinsi Jawa Tengah (Gambar 1). Pengambilan data lapangan menggunakan metode geolistrik resistiviti konfigurasi Schumberger dengan panjang bentangan $250 \mathrm{~m}$. Sedangkan pengolahan data geolistrik dilakukan menggunakan perangkat lunak Ip2Win untuk mendapatkan gambaran konfigurasi akuifer daerah penelitian. Bersamaan dengan pengambilan data geolistrik juga dilakukan pengamatan secara visual terhadap kondisi geologi melalui singkapan yang dijumpai dan kondisi geohidrologinya terutama keberadaan sumur dan mata air. Kondisi akuifer hasil interpretasi data geolistrik resistiviti dengan didukung data hasil pengamatan geologi dan hidrogeologi serta data sekunder berupa hasil pumping test pada lokasi di sebelah timur lokasi penelitian. Berdasarkan data-data tersebut dilakukan analisa untuk mendapatkan potensi air tanah di daerah yang bersangkutan. Lokasi kajian berada di dataran alluvial pantai berpotensi intrusi air laut. Oleh karena itu dilakukan analisa kualitas air tanah dan analisis hidrokimia secara sederhana dengan metode Chlorida-Bicarbonat Ratio (CBR).

\section{Hasil dan Pembahasan}

Berdasarkan pengamatan lapangan wilayah pesisir Kangkung Kabupaten
Kendal terletak pada morfologi dataran dengan kelerengan kurang daru $2^{\circ}$ dan elevasi 25 - 30 m diatas muka air laut ratarata. Daerah ini merupakan bagian dari dataran pantai utara Jawa Tengah yang tersusun oleh endapan alluvial dan sebagian besar berupa lahan pertanian disamping pemukiman. Pola aliran sungai umunya berpola parallel dan sebagian besar berupa saluran irigasi. Berdasarkan pengamatan di lapangan dan mengacu pada tatanan geologi regional, maka diketahui bahwa stratigrafi daerah penelitian tersusun oleh endapan alluvial yang berupa lempung, lanau dan pasir. Ketebalan endapan alluvial tersebut sangat bervariasi hingga mencapai lebih dari $100 \mathrm{~m}$. Endapan alluvial ini menumpang secara tidak selaras di atas Formasi Damar yang tersusun oleh batupasir tufaan, konglomerat, dan breksi volkanik. Batupasir mengandung mineral mafik, feldspar dan kuarsa. Breksi volkanik mungkin diendapkan sebagai lahar. Formasi yang berumur Pleistosen Awal ini sebagian non marin, ditemukan moluska setempat dan sisa verteberata (Thanden, et al. (1996).

Berdasarkan Peta Hidrogeologi Lembar Pekalongan (Tabrani, et al... 1985), maka daerah Kendal dan sekitarnya mempunyai kondisi akuifer yang beragam dari akuifer dengan produktivitas tinggi

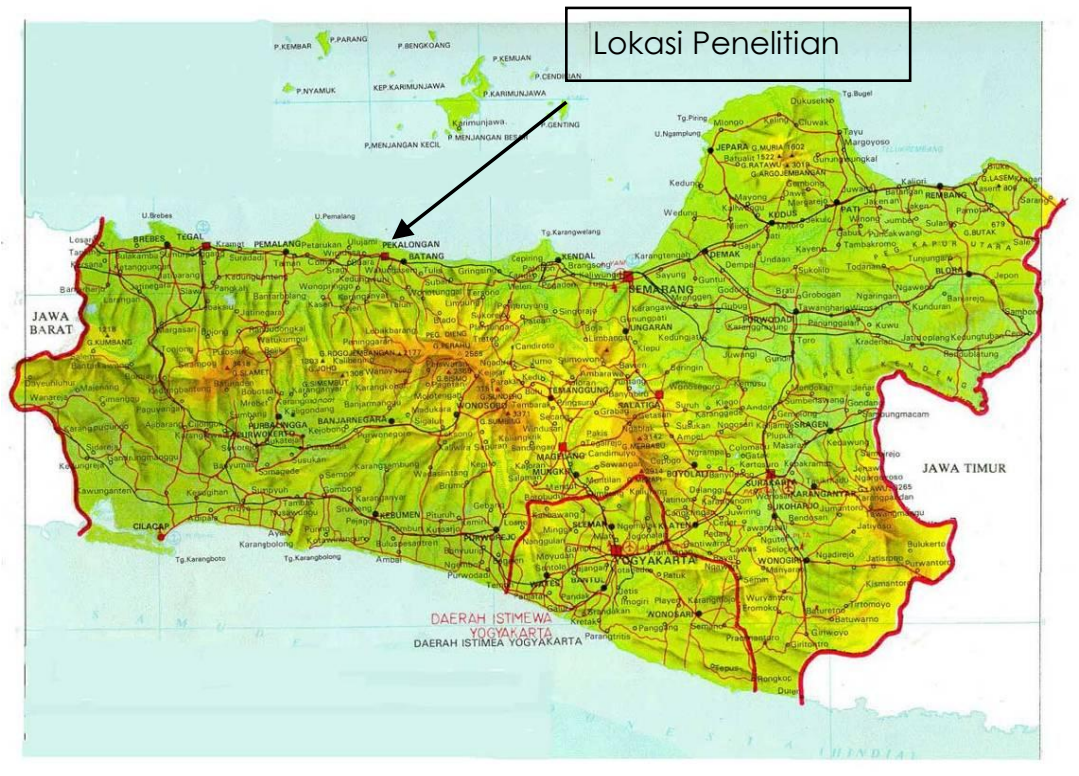

Gambar 1. Peta Lokasi Penelitian 
yang berupa akuifer dengan aliran melalui celah dan ruang antar butir (Gambar 2). Berdasarkan kondisi geologi lokal, hidrogeologi regional, dan pengamatan di lapangan maka dapat diketahui bahwa airtanah di daerah Daerah Kangkung dijumpai secara setempatsetempat. Pada beberapa bagian bahkan dijumpai air tanah dalam kondisi payau hingga asin. Muka air tanah dangkal di daerah ini berkisar antara 2 - 3 $\mathrm{m}$ di bawah muka tanah setempat dan air tanahnya kebanyakan mempunyai kesadahan yang tinggi. Air tanah dangkal di dalam kondisi kering pada musim kemarau. Sedangkan akuifer dalam (tertekan) mempunyai kedalaman sekitar $80 \mathrm{~m}$ di bawah muka tanah setempat.

Hasil pengukuran geolistrik resistiviti yang digambarkan dalam penampang geologi (Gambar 3) memberikan gambaran bahwa susunan litologi daerah kajian secara umum merupakan material lempung, lanau, dan pasir yang secara regional terlihat merupakan bagian dari endapan alluvial yang menumpang diatas batupasir Formasi Damar. Sedangkan bagian paling atas merupakan tanah penutup berupa lempung, lanau pasir dan gravel dan material perkerasan jalan. Secara keseluruhan tata urutan litologi tersebut dari terbawah :

a. Batupasir

Batuan ini merupakan litologi terbawah yang dapat dijangkau oleh geolistrik dan terdeteksi hanya dititik 03 dan sekitarnya, mempunyai resistiviti 41,6 ohm dan dijumpai pada kedalaman $130 \mathrm{~m}$ di bawah permukaan tanah setempat.

b. Lempung

Batuan ini mempunyai resistiviti 1,2 7,4 ohm, ketebalannya tidak terdeteksi. Lapisan ini diperkirakan merupakan lapisan kedap air di daerah penelitian yang diharapkan berfungsi sebagai penyekat sehingga air tanah di atasnya tidak turun.

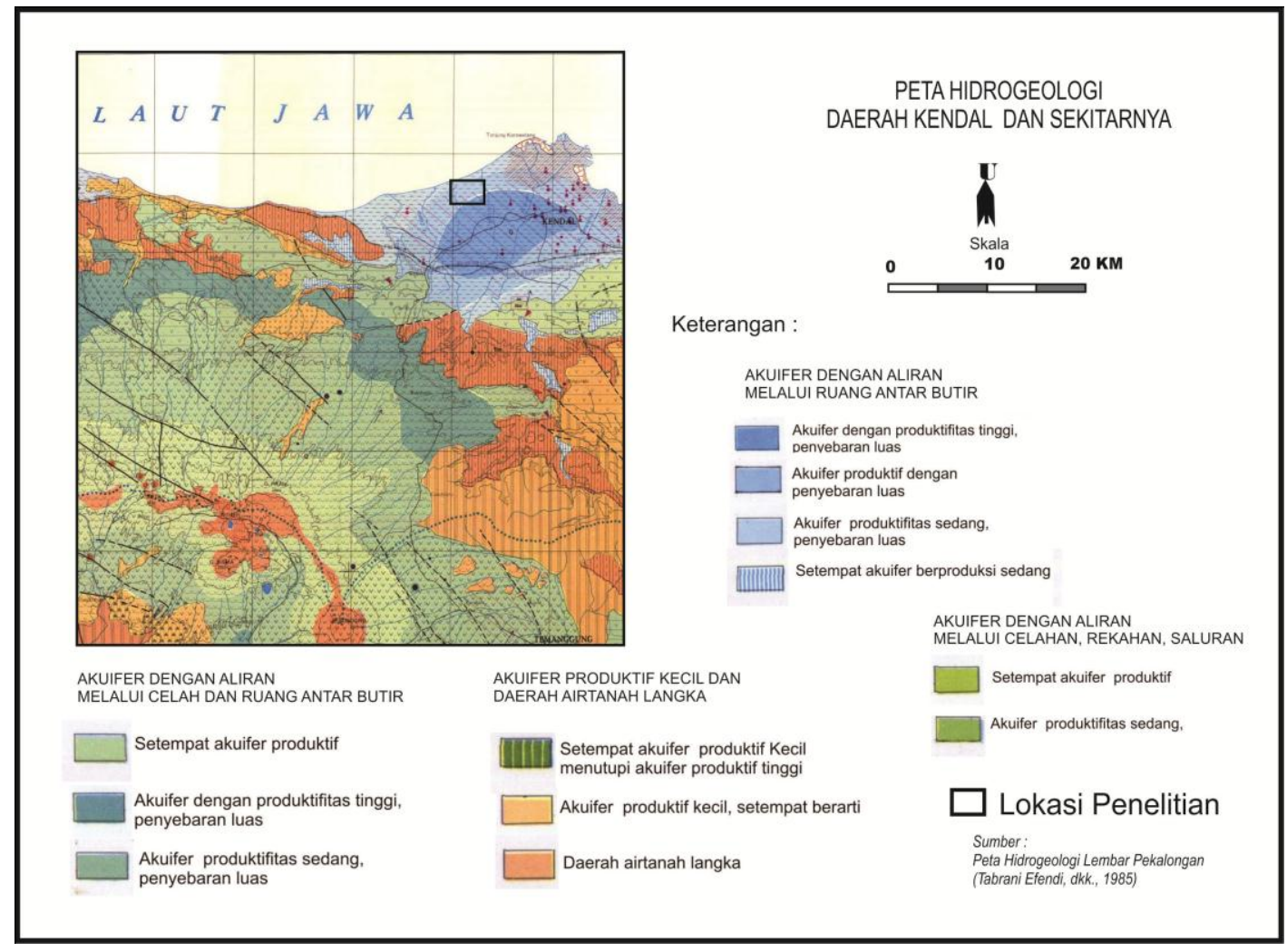

Gambar 2. Peta Hidrogeologi Regional Kabupaten Kendal dan Sekitarnya (Diambil dan disederhanakan dari Tabrani, et al. 1985). 
C. Pasir

Litologi pasir ini mempunyai resistiviti yang bervariasi dari 17,5 - $23-11,3$ ohm-meter dengan ketebalan 35,4 93,5 m. Berdasarkan potongan geolistrik pada Gambar 3. terlihat bahwa litologi ini mempunyai kemiringan dan membentuk cekungan di titik 04.

d. Lanau

Satuan litologi ini mempunyai resistiviti 2,2 - 8,1 ohm-meter dengan ketebalan berkisar antara 12,6 - 113 $\mathrm{m}$. Lapisan ini merupakan lapisan kedap yang memisahkan akuifer dangkal dan akuifer dalam.

e. Pasir lanauan

Litologi ini terdeteksi mempunyai resistiviti 10,2 - 17,2 ohm-meter dengan ketebalan berkisar antara 5 - 15,5 m. Lapisan ini sebagai akifer air tanah dangkal.

f. Lempung

Litologi ini mempunyai resistiviti 2,5 4,5 ohm-meter dan dengan ketebalan maksimum 0,7 - 2,6 m. Dibeberapa tempat lapisan ini menghabat laju infiltrasi air hujan ke akuifer dangkal.

g. Lapisan penutup dan perkerasan jalan Litologi ini mempunyai resistiviti 4,2 12,6 ohm dengan ketebalan 1,1 1,4. Lapisan ini merupakan lapisan teratas yang termasuk di dalamnya material perlapisan jalan berupa pasir, kerikil dan gravel.

Berdasarkan uraian hasil interpretasi data geolistrik tersebut diatas dan dikaitkan dengan tatanan geologi regional, maka dapat dianalisis lebih lanjut bahwa di daerah penyelidikan memungkinkan ditemukan air bawah tanah, baik pada akifer dangkal maupun dalam. Hal ini terlihat dengan dijumpainya lapisan pasir yang diperkirakan relatif porous dan mengandung air sehingga resistivitinya lebih tinggi dibanding lapisan lainnya diduga lempung. Memperhatikan kemiringan lapisan batuan, seperti tampak pada Gambar 3 maka kemungkinan besar airtanah dalam akan dijumpai di sekitar titik 01 dan 04. Pada lokasi tersebut dijumpai litologi dengan resistiviti diatas $15 \mathrm{ohm}$. Dengan demikian pada titik ini potensial untuk dilakukan pemboran pada kedalaman sekitar 100 $m$. Sedangkan air tanah dangkal ditemukan di seluruh daerah kajian dengan kedalaman yang bervariasi dari 2 $-3 \mathrm{~m}$.

Hasil pumping test pada sumur yang berada tepat di sebelah timur lokasi penelitian dan diduga masih mempunyai kondisi akuifer yang sama memberikan hasil Kelulusan 23,86 m/hr, Keterusan $214,77 \mathrm{~m}^{2} / \mathrm{hr}$ dan Kapasitas Jenis 0,61 $\mathrm{l} / \mathrm{dt} / \mathrm{m}$. Berdasarkan penampang di atas, ketebalan rata-rata akuifer adalah 47,76 $\mathrm{m}$, sehingga debit air tanahnya adalah 29,13 It/det. Dan mengambil angka aman $60 \%$ maka debit pengambilan air tanah air tanah yang dapat diambil adalah $17,46 \mathrm{It} /$ det dengan waktu pemompaan 18 jam per hari. Mempertimbangkan kebutuhan air tanah untuk pemukiman

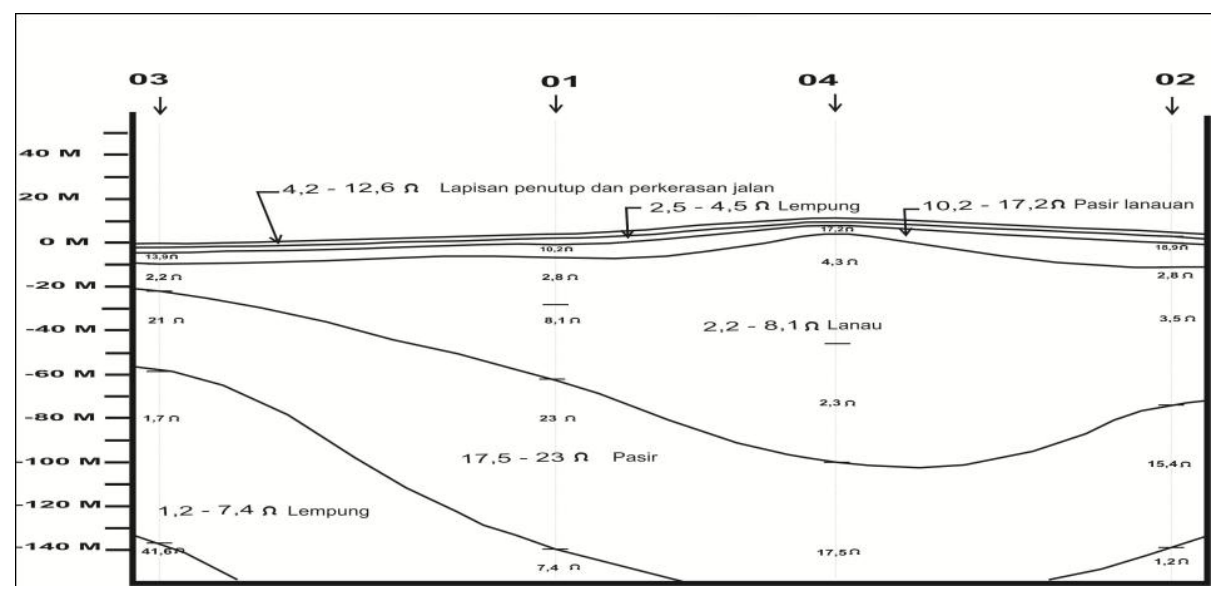

Gambar 3. Penampampang Geologi Hasil Interpretasi Geolitrik Daerah Kangkung 
pedesaan sebesar $60 \mathrm{It} /$ orang/petr hari, maka potensi air tanah di daerah kajian cukup untuk memenuhi penduduk sebanyak 18.800 orang. Berdasarkan data dari Badan Pusat Statistik Kabupaten Kendal, jumlah penduduk Kecamatan Kangkung adalah 48.016 orang. Dengan demikian potensi air tanah tertekan di Kecamatan Kangkung tidak cukup untuk memenuhi kebutuhan air besih seluruh penduduk di kecamatan tersebut. Namun demikian air tanah tersebut cukup untuk memenuhi kebutuhan air bersih di beberapa desa yang selalu mengalami kekeringan pada musim kemarau dengan jumlah penduduk sekitar 7.142 orang.

Hasil analisa kualitas air dari sumur bor yang berada tepat di sebelah timur daerah kajian menunjukan bahwa konduktivitas masih dibawah 1.500 mikro mhos sehingga tergolong sebagai air tawar. Dengan demikian maka airtanah masih dalam kisaran kualitas yang diperbolehkan sebagai sumber air bersih. Untuk mengetahui ada atau tidaknya proses intrusi air laut pada akuifer di daerah penelitian, maka dilakukan analisa dengan Metode Ratio Khlorida Bikarbonat. Perbandingan ion digunakan untuk membantu mengidentifikasi air yang dalam hal ini untuk mengetahui adanya penyusupan air laut (Sugeng, 2007). Perbandingan ion yang digunakan adalah perbandingan ion Khlorida terhadap ion karbonat. Pada air laut, ion $\mathrm{Na}$ dan ion $\mathrm{Cl}$ merupakan ion yang paling dominan. Sedangkan pada daerah pantai pada umumnya air yang terdapat di daerah tersebut kaya akan kandungan ion $\mathrm{Ca}$ dan ion $\mathrm{HCO}_{3}$ (Sihwanto, 1991). Nilai perbandingan Khlorida dan Karbonat lebih besar dari 0,5 menunjukkan adanya penyusupan air laut. Hasil analisa dengan metode ini, diketahui air tanah pada akuifer tertekan di daerah kajian mempunyai nilai Ratio Khlorida Bikarbonat 0,337 yang berarti tidak terjagi instrusi air laut.

Sedangkan berdasarkan hasil analisa laboratorium diperoleh hasil seperti pada Tabel 1 yang didalamnya juga terlihat kaitannya dengan kriteria kualitas air minum sesuai dengan standart Departemen Kesehatan Republik Indonesia. Berdasarkan hasil tersebut, maka secara umum airtanah di daerah penyelidikan merupakan airtanah yang memenuhi syarat sebagai air bersih, kecuali kandungan Fe-nya yang melebihi kadar yang diperbolehkan. Untuk mereduksi kandungan Fe ini maka dapat dilakukan aerasi sebelum digunakan..

Tabel 1. Hasil analis Laboratorium Kualitas Air Tanah

\begin{tabular}{|c|c|c|c|c|}
\hline \multirow{2}{*}{ Unsur } & \multirow{2}{*}{$\begin{array}{c}\text { Maks. } \\
\text { diperbolehkan }\end{array}$} & \multicolumn{2}{|c|}{ Hasil analisa } & \multirow{2}{*}{$\begin{array}{l}\text { Kriteria } \\
\text { Kualitas }\end{array}$} \\
\hline & & Sampel 1 & Sampel 2 & \\
\hline Suhu $\left({ }^{\circ} \mathrm{C}\right)$ & Suhu udara $\pm 3^{\circ}$ & \multicolumn{2}{|c|}{$24,9^{\circ}$} & Baik \\
\hline Warna & Tidak berwarna & \multicolumn{2}{|c|}{ Tidak berwarna } & Baik \\
\hline Bau & Tidak berbau & \multicolumn{2}{|c|}{ Tidak berbau } & Baik \\
\hline Rasa & Tidak berasa & \multicolumn{2}{|c|}{ Tidak berasa } & Baik \\
\hline Turbidity (NTU) & 5 & 3,84 & 1,39 & Baik \\
\hline Konduktivitas $(\mu S)$ & - & 1147 & 883 & Baik \\
\hline TDS (mg/L) & 1.000 & 630 & 485 & Baik \\
\hline $\mathrm{pH}$ & $6,5-8,5$ & 6,59 & 7,21 & Jelek \\
\hline $\begin{array}{l}\text { Kesadahan } \\
\text { (Mg/L) }\end{array}$ & 500 & 346,00 & 66,00 & Baik \\
\hline $\mathrm{Ca}(\mathrm{Mg} / \mathrm{L})$ & 200 & 101,84 & 17,64 & Baik \\
\hline Mg (Mg/L) & 150 & 59,33 & 11,75 & Baik \\
\hline $\mathrm{Fe}(\mathrm{Mg} / \mathrm{L})$ & 0,3 & 0,32 & 0,02 & Baik \\
\hline $\mathrm{Cu}(\mathrm{Mg} / \mathrm{L})$ & 1,5 & 0,26 & 0,02 & Baik \\
\hline $\mathrm{Cl}(\mathrm{Mg} / \mathrm{L})$ & 250 & 175,95 & 56,98 & Baik \\
\hline $\mathrm{NH} 4$ (Mg/L) & 1,5 & 1,43 & 0,04 & Baik \\
\hline $\mathrm{NO}_{2}(\mathrm{Mg} / \mathrm{L})$ & 3 & 0,036 & 0,007 & Baik \\
\hline
\end{tabular}

Baku mutu didasarkan pada SK MENKES No. 492/Menkes/Per/IV2010 


\section{KESIMPULAN}

Akuifer dalam (tertekan) di wilayah Pesisir Kangkung Kabupaten Kendal mempunyai ketebalan rata-rata 47,76 m dan melampar di seluruh daerah dengan kedalaman yang bervariasi dari $60 \mathrm{~m}$ hingga $140 \mathrm{~m}$ di bawah muka tanah setempat. Akuifer ini mempunyai potensi debit air tanah 29,13 It/det. Jika mengambil angka aman $60 \%$ maka debit pengambilan air tanah air tanah yang dapat diambil adalah 17,46 It/det dengan waktu pemompaan 18 jam per hari. Mempertimbangkan kebutuhan air tanah untuk pemukiman pedesaan sebesar 60 It/orang/petr hari, maka potensi air tanah di daerah kajian cukup untuk memenuhi penduduk sebanyak 18.800 orang. Meskipun berbatasan dengan laut, namun air tanah di daerah kajian tidak mengalami terintrusi air laut. Kualitas air tanah di lokasi ini memenuhi syarat sebagai bahan baku air minum sesuai SK Menkes No, 492/Menkes/Per/IV2010 tentang Persyaratan Kualitas Air Minum.

\section{DAFTAR PUSTAKA}

Badan Pusat Statistik Kabupaten Kendal., 2017. Statistik Daerah Kecamatan Kangkung 2016. BPS Kabupaten Kendal.

Departemen Kesehatan RI. 2002. SK MENKES No. 907/MENKES/SK/VII/2002 Tentang Persyaratan Kualitas Air Minum. Depkes RI. Jakarta

Guenerger, A., Harmoko. U., dan Widada, S. 2014. Identifikasi Struktur Bawah
Permukaan Menggunakan Metode Geolitrik Resistiviti Konfigurasi Shlumberger. Di area Panas Bumi Kedalisodo Kecamatan Bergas Kabpaten Semarang. Youngster Physics Journal, Vol. 3 No 3., Hal 279 282

.Heru Hendrayana. 2004. Konsep Dasar Manajemen Cekungan Air Tanah. Teknik Geologi UGM.

Putriutami, E.S., Harmoko. U., dan Widada, S. 2014. Interpretasi Lapisan Bawah Permukaan di Area Panas Bumi Telomoyo Kabupaten Semarang Menggunakan Metode Geolitrik Resistiviti Konfigurasi Shlumberger. Youngster Physics Journal, Vol. 3 No 2., Hal 97 - 106.

Sihwanto dan Satriyo. 1991. Metode Penentuan Penyebab Keasinan Air Tanah : Studi Kasus Daerah Dataran Pantai Dumai, Riau. Kumpulan Makalah Ikatan Ahli Geologi Indonesia. Bandung

Sugeng Widada. 2007. Gejala Intrusi Air Laut di Daerah Pantai Kota Pekalongan. Jurnal Ilmu Kelautan, Vol. 12 No. 1. Hal $45-52$

Tabrani, E., A. 1985. Peta Hidrogeologi Indonesia Lembar Pekalongan, Direktorat Geologi Tata Lingkungan, Bandung

Thanden, RE., Sumadirdja, H., Richards, PW., Sutisna, K. dan Amin, TC. 1996. Peta Geologi Lembar Magelang Semarang. Pusat Penelitian dan Pengembangan Geologi. Bandung 